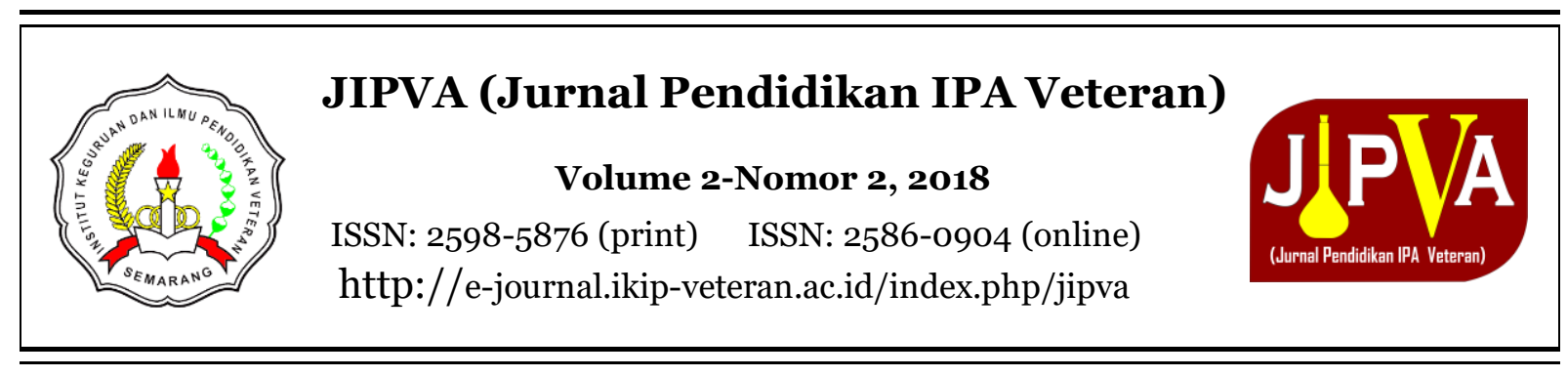

\title{
Pengaruh Pembelajaran IPA Berbasis Empat Pilar Pendidikan Terhadap Kemampuan Berpikir Kritis
}

\author{
Rizki Noor Prasetyono ${ }^{1 *}$, Eka Trisnawati ${ }^{2}$ \\ ${ }^{1}$ Teknik Elektro, Fakultas Sains dan Teknologi, Universitas Peradaban, Indonesia \\ ${ }^{2}$ Farmasi, Fakultas Sains dan Teknologi, Universitas Peradaban, Indonesia \\ *Corresponding author email: pr45t91@gmail.com
}

Received: 27 Agustus 2018; Revised: 25 Oktober ; Accepted: 26 Oktober 2018

\begin{abstract}
Abstrak
Penelitian ini bertujuan untuk mengetahui pengaruh dan efektivitas pembelajaran IPA berbasis empat pilar pendidikan yaitu learning to know, learning to do, learning to live together, and learning to be terhadap kemampuan berpikir kritis. Penelitian ini dilaksanakan di SMP kelas VIII pada mata pelajaran Ilmu Pengentahuan Alam tahun ajaran 2017/2018. Desain penelitian quasi-experiment bentuk Nonequivalent control-group design, dengan mengambil pretes sebelum diberi perlakuan kemudian dilakukan postes. Dari hasil analisis data menunjukkan bahwa nilai signifikansi (p-value) dengan ANCOVA adalah 0,026. Karena nilai signifikansi lebih kecil dari 0,05 maka terdapat pengaruh yang signifikan antara siswa yang menggunakan pembelajaran IPA berbasis empat pilar pendidikan dengan siswa yang menggunakan pembelajaran secara konvensional. Data hasil analisis efektivitas didapatkan nilai probabilitas (Sig.) $0,000<0,05$ artinya pembelajaran IPA berbasis empat pilar pendidikan efektif dalam meningkatkan kemampuan berpikir kritis siswa.
\end{abstract}

Kata Kunci: Empat Pilar Pendidikan, Berpikir kritis, Ilmu Pengetahuan Alam.

\section{The Effect of Four Pillars Education in Science Learning to the Critical Thinking Ability}

\begin{abstract}
The purpose of the research to determine the effect and effectiveness of the four pillars of education in science learning (learning to know, learning to do, learning to live together, and learning to be) to the critical thinking ability. This research was conducted in the eighth grade junior high school in the subject of Natural Science of the academic year 2017/2018. By using a quasiexperimental research design in the Nonequivalent control-group design form, by taking pretest before being treated then post tes. Based on the research data the significance value (p-value) with ANCOVA is 0.026. Because the significance value is less than 0.05, there is a significant influence between students who use science learning based on the four pillars of education with students who use conventional learning. The results of the effectiveness data analysis obtained the probability value (Sig.) 0,000 <0,05 which means that science learning based on four pillars of education is effective in improving student's critical thinking skills.
\end{abstract}

Keywords: Four Pillars of Education, Critical Thinking, Natural Sciences.

How to Cite: Prasetyono, R., \& Trisnawati, E. (2018). Pengaruh Pembelajaran IPA Berbasis Empat Pilar Pendidikan terhadap Kemampuan Berpikir Kritis. JIPVA (Jurnal Pendidikan IPA Veteran), 2(2), 162-173. doi:10.31331/jipva.v2i2.679 


\section{PENDAHULUAN}

Organisasi Pendidikan, Keilmuan, dan Kebudayaan (UNESCO) memberikan kontribusi dalam dunia pendidikan yaitu pendidikan yang didasarkan pada empat pilar yaitu learning to know, learning to do, learning to live together, and learning to be. Empat pilar tersebut menekankan tentang learning (belajar) yang menuntut siswa aktif dalam belajar. Konteks kurikulum 2013 yang diterapkan sekarang berisi kompetensi inti yang meliputi kualitas yang seimbang antara pancapaian hard skill dan soft skill untuk mencakup kompetansi utama yang dikelompokan ke dalam aspek sikap, pengetahuan, dan keterampilan (Kemendikbud, 2012). Maka dari itu, guru diharapkan mampu berinovasi dalam proses pembelajaran berbasis siswa aktif belajar.

Perangkat pembelajaran merupakan pedoman bagi guru untuk melakukan pembelajaran di kelas sehingga tujuan pembelajaran yang diharapkan dapat tercapai. Hal ini bisa dijadikan motivasi bagi guru untuk melakukan inovasi dalam menyusun perangkat pembelajaran yang memiliki komponen yaitu rencana pelakasanaan pembelajaran (RPP), media pembelajaran, buku dan lembar kerja siswa serta sarana dan prasana pendukung lainya.

Susetyo (2008) menyatakan perangkat pembelajaran yang berbasis empat pilar pendidikan menunjukan peningkatan dalam kebiasaan bekerja ilmiah melalui pengembangan model pembelajaran. Siswa juga menunjukan respon yang baik dalam pembelajaran dengan menggunakan perangkat pembelajaran tersebut. Hakim, L., Suparmi, \& Masykuri (2018) dalam penelitiannya juga menyatakan bahwa ada peningkatan ketrampilan proses sains melalui perangkat pembelajran empat pilar pendidikan yaitu learning to know, learning to do, learning to be, dan learning to live together. Hal ini juga didukung dengan penelitian Asih, Supurwoko, \& Fauzi (2015) melalui modul pembelajaran berbasis empat pilar pendidikan memiliki respons yang baik dari siswa. Berdasarkan penelitian tersebut empat pilar pendidikan menjadi sebuah dasar dalam pembelajaran yang bisa diterapkan di pembelajarn.

Perangkat pembelajaran yang berbasis empat pilar pendidikan merujuk pada empat pilar pendidikan yang digagas oleh UNESCO. Integrasi empat pilar pendidikan mampu memberikan efektivitas lebih baik dalam pembelajaran. Dibuktikan dengan penelitian Kiswati (2012) bahwa pembelajaran dengan pendekatan empat pilar pendidikan memenuhi kelayakan dan keefektifan pada aktifitas siswa, sintaks pembelajaran, respon siswa dan hasil belajar siswa. Pembelajaran berbasis empat pilar pendidikan UNESCO memberikan alternatif bagi guru dan siswa untuk belajar dan pembelajaran. Berdasarkan penelitian Fauzi, Supurwoko, \& Wiyono (2013) menyebutkan bahwa dalam empat pilar pendidikan untuk proses learning to know dimana guru memberikan rangsangan untuk siswa dalam memahami materi, proses learning to do membantu siswa untuk membangkitkan rasa ingin tahu melalui tahapan ilmiah, proses learning to live together ini diajarkan bekerjasama dalam berkelompok dan learning to be dengan tahapan ilmiah akan muncul kebiasaan berpikir dan bertindak ilmiah. Apabila keseluruhan siswa mengerjakan sesuai dengan bekerja ilmiah maka siswa telah learning to be yaitu menjadi seorang ilmuan. Tabel 1 menunjukkan indikator empat pilar pendidikan UNESCO (Kiswati ,2012). 
Tabel 1. Indikator Empat Pilar Pendidikan

\begin{tabular}{ll}
$\begin{array}{c}\text { Empat pilar } \\
\text { pendidikan } \\
\text { UNESCO }\end{array}$ & \\
\hline Learning to Know & $>$ Memperoleh dan menguasai materi sebanyak- banyaknya \\
& $>$ Mencari informasi dari lingkungan sekitar dan sumber- sumber \\
& lain. \\
& $>$ Mampu menguasai materi ajar yang diterima \\
& $>$ Mengembangkan dan merespon sumber informasi baru \\
& $>$ Memanfaatkan berbagai sumber pelajaran \\
& $>$ Mengkaitkan pembelajaran dengan kompetensi \\
& $>$ Mengimplementasikan pengetahuan dengan keterampilan \\
& Mengaplikasikan pemahaman secara kreatif dengan tindakan di \\
& $>$ Meningkatkan keterampilan dalam pemecahan masalah \\
& $>$ Berkreasi dengan pengetahuan yang telah diperoleh \\
\hline Learning to do & Menerapkan nilai- nilai kebersamaan yang ada di kelas. \\
& $>$ Mampu bertoleransi dengan siswa yang lain \\
& $>$ Saling menghargai jika terjadi perbedaan pendapat \\
& $>$ Mengenal kekurangan dan kelebihan diri sendiri \\
& $>$ Menunjukkan sikap percaya diri \\
& $>$ Menunjukkan kemampuan belajar secara mandiri sesuai dengan \\
& potensi yang dimilikinya \\
& $>$ Belajar untuk dapat mandiri \\
& $>$ Belajar menjadi orang yang bertanggung jawab sehingga dapat \\
& mencapai tujuan yang diharapkan \\
& $>$ Dapat mengembangkan kepribadian sehingga mampu melakukan \\
& hal besar dan dapat dipertanggungjawabkan \\
\hline Learning to live &
\end{tabular}

Beradasarkan dari kajian diatas dapat disimpulkan bahwa empat pilar pendidikan UNESCO adalah tiang atau penyangga konstruksi berdasarkan belajar untuk mengetahui (learning to know), belajar melakukan seseatu (learning to do), belajar menjadi seseorang (learning to be), dan belajar untuk bekerja sama (learning to live together) dalam proses penyaluran pengetahuan budaya, dan pengembangan pemahaman konseptual diwujudkan dalam sikap, kemampuan berpikir, kemampuan memecahkan masalah, dan kreativitas bertujuan untuk pendewasaan anak.

Pada kenyataannya skala literasi sains menurut PISA, siswa SMP di Indonesia tahun 2015 menunjukan nilai rata-rata yaitu
403 poin dimana nilai tersebut jauh di bawah negara Singapura, Filipina, dan Thailand. Pada tujuan pembelajaran IPA, penguasaan konsep literasi sains sangat dibutuhkan dalam pembelajaran. Penguasaan konsep memberikan bantuan siswa dalam mendefinisikan konsep. Menurut I Wayan (2009) pembelajaran IPA membutuhkan kemampuan literasi sains dan pola pikir dalam memahami gejala dan fenomena alam. Siswa harus memiliki kemampuan berpikir kritis agar memiliki kemampuan literasi sains dan sikap ilmiah. Alfathy, Susanto, \& Marwoto (2018) menyatakan bahwa siswa dengan sikap ilmiah yang baik dapat meningkatkan 
Rizki Noor Prasetyono, Eka Trisnawati

kemampuan berpikirnya sehingga lebih termotivasi untuk meningkatkan prestasinya.

Berpikir kritis memberikan kerangka kerja bagi siswa untuk membentuk kemampuan dan pola pikir saintifik.

Pembelajaran pada kurikulum 2013 membutuhkan siswa aktif dalam proses belajar dan pembelajaran. Salah satu yang membuat siswa aktif yaitu membuat siswa mampu berpikir kritis. Hal ini sesuai dengan penelitian Yuliati, Yulianti, \& Khanafiyah, (2011) yaitu pembelajaran fisika dengan menumbukan kemampuan berpikir kritis dapat meningkatkan hasil belajar siswa. Siswa yang diberikan pengalaman berpikir kritis mampu meningkatkan tingkat penguasaan konsep dan hasil belajar siswa.

Berpikir kritis terdiri dua kata yaitu "berpikir" dan "kritis" menurut Kamus Besar Bahasa Indonesia berpikir artinya menggunakan akal budi dalam mempertimbangkan dan memutuskan sesuatu kemudian kritis yang artinya bersifat tidak mudah percaya, tajam dalam penganalisisan. Johnson (2009) menyatakan bahwa berpikir kritis dan berpikir kreatif merupakan bagian dari High Order Thinking (berpikir tingkat tinggi). Jadi berpikir kritis adalah kerangka akal budi yang digunakan untuk menganalisis dalam mempertimbangakan dan memutuskan sesuatu agar bisa diterima logika. Dalam Ennis (1985) menjelaskan keterampilan berpikir kritis terdiri dari : 1) Menilai sumber yang kredibel; 2) Mengidentifikasi alasan, asumsi, kesimpulan; 3) Menilai dalam argumen yang tibul, asumsi dan bukti; 4) Mengembangkan dan mempertahankan dalam menyelesaikan suatu masalah; 5) Mengajukan klarifikasi yang tepat; 6) Merencanakan eksperimen dan menilai rancangan eksperimen; 7)
Mengartikan istilah dalam cara yang tepat untuk konteks; 8) Berpikiran terbuka; i)Diinformasikan dengan baik; 9) Mengambil kesimpulan dengan cermat dan hati-hati.

Butler (2012) menyatakan bawa dalam berpikir kritis memiliki tujuan dalam pembelajaran yaitu : 1) Membangun kecerdasan dan kemampuan kognitif; 2)Memahami proses dalam penerepan kehidupan sehari-hari; 3)Kebiasan untuk menerapkan dalam berpikir kritis; 4) Membantu siswa dalam melakukan keputusan.

Kabupaten Brebes sudah menerapkan kurikulum 2013 khususnya di SMP, akan tetapi masih belum maksimal dalam menerapkan belajar siswa aktif dan bepikir kritis. Hal ini dibuktikan dengan hasil observasi di SMP Negeri 1 Bumiayu, pembelajaran masih menekankan pada ceramah untuk mendapatkan pengetahuan. Jumlah siswa yang memiliki kemampuan berpikir kritis baik tidak lebih dari 30\% dan hanya siswa putri. Begitu juga terkait 4 pilar pendidikan, dalam aplikasi pembelajaran di SMP Negeri 1 Bumiayu pada umumnya sudah menerapkannya, namun, hanya siswa yang aktif yang dapat menerima penerapan konsep pembelajaran tersebut. Sekitar 70\% sampai $80 \%$ siswa pasif dan cenderung hanya dapat menerima pembelajaran secara terbimbing. Hal ini menunjukan bahwa pembelajaran tidak berpusat pada siswa atau dengan kata lain siswa tidak aktif dalam pembelajaran dan kurang dalam kemampuan berpikir kritis.

Berdasarkan hal tersebut, dibutuhkan pembelajaran yang mendukung kurikulum 2013 yaitu pembelajaran IPA berbasis empat pilar pendidikan UNESCO. Pembelajaran berbasis empat pilar 
pendidikan mempunyai tujuan membuat pendidikan yang berkelanjutan (seumur hidup) seperti keterampilan untuk melakukan sesuatu dengan proses ilmiah (learning to do), kerjasama satu sama lain terjadi interaksi (learning to live together), belajar untuk mengetahui sesuatu dari proses yang dilakukan secara ilmiah (learning to know), dan belajar menjadi ilmuan (learning to be) (Muslikha, 2010).

\section{METODE}

\section{Jenis Penelitian}

Jenis penelitian ini adalah penelitian eksperimen menggunakan desain penelitian quasi-experiment bentuk Nonequivalent control-group design. Desain ini dilaksanakan untuk menyelidiki pengaruh pembelajaran berbasis empat pilar pendidikan terhadap kemampuan berpikir kritis siswa sesuai dengan Tabel 2.

Tabel 2. Desain Penelitian Nonequivalent Control-Group Design

\begin{tabular}{lccc}
\hline Kelompok & Pretest & Perlakuan & Posttest \\
\hline $\begin{array}{l}\text { Kelas } \\
\text { kontrol }\end{array}$ & $O_{1}$ & $X_{1}$ & $O_{2}$ \\
\hline $\begin{array}{l}\text { Kelas } \\
\text { eksperimen }\end{array}$ & $O_{3}$ & $X_{2}$ & $O_{4}$ \\
\hline Keterangan : & & \\
$O_{1}$ dan $O_{3}:$ & $\begin{array}{l}\text { Pretes pada kelas eksperimen } \\
\text { dan pretes kelas kontrol }\end{array}$ \\
$O_{2}$ dan $O_{4}:$ & $\begin{array}{l}\text { Postes pada kelas eksperimen } \\
\text { dan pretes kelas kontrol } \\
X_{1}\end{array}$ & $\begin{array}{l}\text { Pembelajaran IPA berbasis } \\
\text { empat pilar pendidikan }\end{array}$ \\
& $\begin{array}{l}\text { UNESCO } \\
X_{2}\end{array}$ & $\begin{array}{l}\text { Pembelajaran IPA dengan } \\
\text { konvensional }\end{array}$
\end{tabular}

\section{Subjek Penelitian}

Populasi dalam penelitian ini adalah semua siswa SMP Negeri 1 Bumiayu kelas VIII memiliki tiga kelas yaitu kelas VIII A,
VIII B, dan VIII C di tahun pelajaran 2017/2018. Dengan mengunakan metode cluster random sampling. Didapatkan Kelas Kontrol yang tidak diberi perlakuan, yaitu kelas VIII B. Kelas Eksperimen yang diberi perlakuan atau, yaitu kelas VIII A.

\section{Prosedur}

Tahap awal penelitian ini dilakukan untuk mengetahui kebutuhan guru pada pembelajaran yang bisa digunakan untuk memngembangkan kemampuan siswa berpikir kritis. Pada tahap ini dilakukan pemilihan sekolah yang akan diteliti, pemilihan kelas yang akan diteliti dengan cluster random sampling, observasi secara langsung dalam pembelajaran, menganalisis data nilai ujian akhir semester (UAS) ganjil untuk menentukan apakah kelas dalam keadaaan sama atau homogen sebelum dilakukan penelitian, menyusun pembelajaran dengan menggunakan empat pilar pendidikan, menyusun instrument penilaian, melakukan uji coba instrument penilaian pada kelas uji coba, menganalisis data hasil uji coba instrument penilaian, dan menentukan instrument penilaian yang layak digunakan dalam penelitian.

Pada tahap ini dilakukan menyusun hasil pengambilan data penelitian pada kelas eksperimen dan kelas kontrol. Kemudian menganalisis data tersebut untuk membuktikan hipotesis penelitian.

\section{Hipotesis Penelitian}

$\mathrm{Ha}_{1}$ : Pembelajaran IPA berbasis empat pilar pendidikan berpengaruh terhadap kemampuan berpikir kritis siswa.

$\mathrm{Ha}_{2}$ : Pembelajaran IPA berbasis empat pilar pendidikan efektif meningkatkan kemampuan berpikir kritis siswa.

$\mathrm{Ho}_{1}$ : Pembelajaran IPA berbasis empat pilar pendidikan tidak berpengaruh 
Rizki Noor Prasetyono, Eka Trisnawati

terhadap kemampuan berpikir kritis siswa.

$\mathrm{Ho}_{2}$ : Pembelajaran IPA berbasis empat pilar pendidikan tidak efektif meningkatkan kemampuan berpikir kritis siswa.

\section{Instrumen dan Teknik Analisis Data}

Instrumen yang digunakan adalah tes pilihan ganda untuk mengukur kemampuan berpikir kritis siswa. Instrument tes terdiri dari soal kemampuan awal dan kemampuan akhir berupa tes pilihan ganda.

Analisis data instrument tes pilihan ganda berupa validitas digunakan untuk mengukur ketepatan dan kecermatan terhadap butir soal dalam instrumen tes, reliabilitas mengukur konsistensi dari instrumen tes yang akan digunakan dalam penelitian, taraf kesukaran, dan daya pembeda untuk membedakan antara siswa yang kelompok atas dan kelompok bawah.

Analisis data penelitian dengan bantuan SPSS 16 for windows, meliputi Uji normalitas dalam penelitian ini menggunakan uji Kolmogorof-Smirnov Kriteria keputusan yaitu jika nilai signifikasi ( $P$-value $)$ lebih besar dari 0,05 sampel berasal dari populasi yang berdistribusi normal. Uji homogentitas menggunakan statistik uji Levene dengan taraf signifikansi $5 \%$. Kriteria keputusan yaitu jika nilai signifikasi ( $P$-value) lebih besar dari 0,05 maka dapat dikatakan bahwa varians antar kelompok sama/homogen. Soal tes uji coba dengan jumlah soal 30 butir yang dianalis dan dipilih melalui ketentuan bahwa soal tersebut berdasarkan validitas maupun reliabilitas didukung dengan daya pembeda dan tingkat kesukarannya.
Tabel 3. Analisisi validitas dan reliabilitas

\begin{tabular}{ccccc}
\hline No & Validitas & Kategori & Reliabiltas & Kategori \\
\hline 1 & 0,6 & Valid & 0,41 & Cukup \\
2 & 0,5 & Valid & 0,68 & reliabel \\
3 & 0,4 & Valid & 0,80 & reliabel \\
4 & $-0,4$ & Drop & 0,65 & reliabel \\
5 & 0,5 & Valid & 0,87 & reliabel \\
6 & 0,5 & Valid & 0,50 & reliabel \\
7 & 0,42 & Valid & 0,85 & reliabel \\
8 & $-0,4$ & Drop & 0,84 & reliabel \\
9 & 0,5 & Valid & 0,60 & reliabel \\
10 & 0,3 & Valid & 0,84 & reliabel \\
11 & 0,5 & Valid & 0,76 & reliabel \\
12 & 0,5 & Valid & 0,75 & reliabel \\
13 & $-0,2$ & Drop & 0,56 & reliabel \\
14 & 0,5 & Valid & 0,80 & reliabel \\
15 & 0,3 & Valid & 0,76 & reliabel \\
16 & 0,4 & Valid & 0,72 & reliabel \\
17 & 0,4 & Valid & 0,67 & reliabel \\
18 & 0,3 & Valid & 0.78 & reliabel \\
19 & 0,3 & Valid & 0.57 & reliabel \\
20 & $-0,2$ & Drop & 0.86 & reliabel \\
21 & 0,4 & Valid & 0.68 & reliabel \\
22 & 0,4 & Valid & 0.76 & reliabel \\
23 & 0,23 & Drop & 0.80 & reliabel \\
24 & 0,7 & Valid & 0.65 & reliabel \\
25 & 0,4 & Valid & 0.65 & reliabel \\
26 & 0,3 & Valid & 0,50 & reliabel \\
27 & 0,7 & Valid & 0,76 & reliabel \\
28 & 0,4 & Valid & 0,87 & reliabel \\
29 & 0,4 & valid & 0,90 & reliabel \\
30 & 0,5 & valid & 0,60 & reliabel \\
\hline & & & & \\
& & &
\end{tabular}

Validitas instrumen soal dengan menggunakan korelasi produk moment angka kasar. Kriteria perhitungan $r_{x y}$ dibandingkan dengan $r_{x y}$ tabel dengan taraf signifikansi $5 \%$. Jika didapatkan $r_{x y}$ hitung $>$ $\mathrm{r}_{\mathrm{xy}}$ tabel, maka dikatakan bahwa butir soal instrumen tersebut valid. Tabel 3 menunjukan hasil perhitungan didapatkan 5 soal tidak valid yaitu butir soal dengan nomor 4, 8, 13, 20, dan 23. Kelima soal 
tersebut tidak memenuhi validitas butir soal karena harga $r_{x y}<r_{\text {Tabel }}$ dimana harga $r_{\text {Tabel }}=$ 0,334 .

Realibilitas instrumen soal menguji reliabilitas suatu instrumen, dapat digunakan rumus KR-20. Kriteria perhitungan $\mathrm{r}_{11}$ hitung dibandingkan dengan $\mathrm{r}$ tabel dengan taraf signifikansi $5 \%$. Jika didapatkan $\mathrm{r}_{11 \text { hitung }}>\mathrm{r}$ tabel, maka dikatakan bahwa instrumen tersebut reliabel. Berdasarkan Tabel 3 hasil perhitungan data diperoleh dari 30 butir soal mememenuhi data reliabel.

Kemudian perhitungan daya pembeda dari hasil rekapitulasi dengan kriteria klasifikasi daya pembeda (DP) soal sebagai berikut :

$$
\begin{array}{ll}
\mathrm{DP} \leq 0,00 & =\text { Sangat jelek } \\
0,00 \leq \mathrm{DP} \leq 0,20 & =\text { Jelek } \\
0,20 \leq \mathrm{DP} \leq 0,40 & =\text { Cukup } \\
0,40 \leq \mathrm{DP} \leq 0,70 & =\text { Baik } \\
0,70 \leq \mathrm{DP} \leq 1,00 & =\text { Sangat baik }
\end{array}
$$

Dari hasil perhitungan diperoleh butir soal berkriteria sangat baik yaitu nomer 4 ; butir soal berkriteria baik dengan nomer 2 , 5, 6, 9, 11, 12, 14, 16, 24, 27, 28, dan 30; butir soal berkriteria cukup dengan nomor 1 , 7, 10, 15, 17, 18, 19, 21, 25, 26, dan 29. Kemudian butir soal berkriteria jelek 3, 8, 13, 20, 22, dan 23 dengan klasifikasi DP $\leq$ 0.20 .

Analisis memilah instrumen soal dengan kriteria mudah, sedang, dan sukar, bertujuan untuk memberikan soal yang tidak terlalu sukar dan tidak terlalu mudah. Berdasarkan hasil perhitungan didapatkan butir soal sukar dengan nomor 11, 17 dan 19; butir soal sedang dengan nomor 1, 2, 4, $5,7,8,9,10,14,15,18,21,24,25,27$, dan 30. Kemudian untuk butir soal mudah dengan nomer $3,6,12,13,16,20,22,23$, 26, 28, dan 29.
Analisis data untuk mengetahui pengaruh pembelajaran IPA berbasis empat pilar pendidikan terhadap kemampuan berpikir kritis yaitu menggunakan uji statistik analisis kovarian (ANACOVA) dengan taraf signifikansi 5\%. Kriteria keputusan yaitu jika nilai signifikasi ( $P$ value $) \leq 0,05$ maka $\mathrm{Ho}_{1}$ ditolak atau artinya ada pengaruh pembelajaran IPA berbasis empat pilar pendidikan terhadap kemampuan berpikir kritis.

Analasis data dalam keefektivitasan pembelajaran IPA berbasis empat pilar pendidikan terhadap kemampuan berpikir kritis menggunakan Uji statistik analisis ujit dua pihak (two tail) tipe 2 sampel berpasangan (two paired sample) dengan taraf signifikansi 5\%. Kriteria keputusan yaitu jika nilai signifikasi (2-tailed) $\leq 0,05$ maka $\mathrm{Ho}_{2}$ ditolak atau artinya ada peningkatan efektivitas pembelajaran IPA berbasis empat pilar pendidikan terhadap kemampuan berpikir kritis.

\section{HASIL DAN PEMBAHASAN}

Penelitian ini dilaksanakan di SMP Negeri 1 Bumiayu, Kecamatan Bumiayu, Kabupaten Brebes dengan subjek penelitian siswa kelas VIII A sebagai kelompok eksperimen 1 yaitu sebanyak 32 siswa, yang terdiri dari 12 siswa laki-laki dan 20 siswa perempuan, serta siswa kelas VIII B sebagai kelompok kontrol yaitu sebanyak 32 siswa, yang terdiri dari 12 siswa laki-laki dan 20 siswa perempuan. Penelitian ini dilakukan pada pembelajaran IPA dengan materi Cahaya dan Alat Optik.

Proses pembelajaran pada kelas eksperimen dengan empat pilar pendidikan dengan menggunakan sintaks pembelajaran kooperatif empat pilar pendidikan dari penelitian pengembangan Susetyo. Menurut Susetyo (2008) pengembangan model pembelajaran kooperatif berbasis empat 
Rizki Noor Prasetyono, Eka Trisnawati

pilar pendidikan dengan sintaks pembelajaran berikut :

Fase 1 : menjelaskan tujuan, materi dan motivasi kepada siswa.

Fase 2 : memberikan informasi materi, bahan pembelajaran, demonstrasi dan tahapan praktikum.

Fase 3 : membentuk kelompok 4-5 siswa untuk belajar dalam aspek belajar untuk mengetahui (learning to know), belajar melakukan seseatu (learning to do), belajar menjadi seseorang (learning to be), dan belajar untuk bekerja sama (learning to live together).

Fase 4 : membimbing dan memfasilitasi kelompok dalam belajar dan bekerja.

Fase 5 : Evaluasi dan mempresentasikan hasil kerja dan belajar kelompok.

Fase 6 : Memberikan penghargaan

Uji normalitas dilakukan pada nilai pretest dan postest di kelas eksperimen maupun kelas kontrol. Analisis statistik menggunakan uji Kolmogorov-Smirnov yang dihitung menggunakan program SPSS 16 for windows. Hasil uji normalitas data pretest disajikan pada Tabel 4 sedangkan hasil uji normalitas data postes disajikan pada tabel 5 .

Tabel 4. Hasil Uji Normalitas Data Pretest

\begin{tabular}{llll}
\hline \multicolumn{1}{c}{ Kelas } & $\begin{array}{l}\text { Probabilitas } \\
\text { (signifikansi) }\end{array}$ & (p) sig & Ket. \\
\hline Eksperimen & 0,127 & $\mathrm{P}>0,05$ & Normal \\
Kontrol & 0,079 & $\mathrm{P}>0,05$ & Normal \\
\hline
\end{tabular}

Berdasarkan Tabel 4, data tersebut menunjukkan bahwa sebaran data nilai pretest pada kelas ekperimen dan kelas kontrol memiliki nilai signifikan ( $p$-value) lebih besar dari 0,05 . Hal ini berarti sampel dari kelas kontrol dan kelas eksperimen berasal dari populasi yang berdistribusi normal berdasarkan data pretest.

Tabel 5. Hasil Uji Normalitas Data Postest

Kelas Probabilitas (p) sig Ket.

\begin{tabular}{ccl}
\multicolumn{3}{c}{ (signifikansi) } \\
\hline Eksperimen & 0,098 & $\mathrm{P}>$ Normal \\
Kontrol & 0,200 & 0,05 \\
& & $\mathrm{P}>$ Normal \\
& 0,05 \\
\hline
\end{tabular}

Berdasarkan Tabel 5, data tersebut menunjukkan bahwa sebaran data nilai postes pada kelas ekperimen dan kelas kontrol memiliki nili signifikan ( $p$-value) lebih besar dari 0,05. Hal ini berarti sampel dari kelas kontrol dan kelas eksperimen berasal dari populasi yang berdistribusi normal berdasarkan data postest.

Tabel 6. Hasil Uji Homogenitas Kelas Eksperimen dan Kelas Kontrol

\begin{tabular}{cccc}
\hline $\begin{array}{l}\text { Levene } \\
\text { Statistic }\end{array}$ & df1 & df2 & Sig \\
\hline 0,182 & 4 & 24 & 0,945 \\
\hline Uji & homogenitas & bertujuan & untuk
\end{tabular}
mengetahui apakah sampel berasal dari populasi yang homogen atau tidak. Analisis statistik yang digunakan pada penelitian ini adalah dengan menggunakan uji Levene program SPSS 16 for windows dengan taraf signifikansi 0,05. Hasil uji homogenitas disajikan pada Tabel 6.

Berdasarkan Tabel 6, menunjukkan bahwa nilai signifikansi ( -value) lebih besar dari 0,05. Berdasarkan kriteria pengambilan keputusan dapat dikatakan bahwa tidak terdapat perbedaan varians antara kelas eksperimen dan kelas kontrol pada kemampuan awal, hehingga dapat disimpulkan data memiliki varians sama atau homogen dan selanjutnya dapat dilakukan uji statistik parametik. 
Uji statistik untuk mengetahui pengaruh pembelajaran IPA berbasis empat pilar pendidikan terhadap kemampuan berpikir kritis dalam penelitian ini menggunakan uji Analisis Covarian (ANCOVA). Adapun hasil uji statistik disajikan pada Tabel 7.

Tabel 7. Hasil Uji Statistik ANCOVA

\begin{tabular}{ccccc}
\hline & F & Sig & A & Kesimpulan \\
\hline Kelas & 3883 & 0,026 & 0,05 & $\mathrm{H}_{0}$ diTolak
\end{tabular}

Tabel 7 menunjukkan bahwa nilai signifikansi ( $p$-value) dengan ANCOVA adalah 0,026. Nilai signifikansi lebih kecil dari 0,05 sehingga berdasarkan kriteria pengambilan keputusan $\mathrm{Ho}_{1}$ yang menyatakan "tidak ada pengaruh kemampuan berpikir kritis yang signifikan antara kelas kontrol dengan kelas ekperimen dalam pembelajaran IPA berbasis empat pilar pendidikan“ ditolak. Berdasarkan hal tersebut dapat disimpulkan bahwa terdapat pengaruh yang signifikan antara siswa yang menggunakan pembelajaran IPA berbasis empat pilar pendidikan dengan siswa yang menggunakan pembelajaran secara konvensional.

Uji statistik untuk mengetahui efektivitas pembelajaran IPA berbasis empat pilar pendidikan terhadap kemampuan berpikir kritis dalam penelitian ini yaitu menggunakan analisis uji-t dua pihak (two tail) tipe 2 sampel berpasangan (two paired sample) dengan taraf signifikansi 5\% dengan menggunakan bantuan SPSS 16 for windows. Adapun hasil uji statistik disajikan pada Tabel 8.

Berdasarkan tabel 8, didapatkan nilai $\mathrm{p}<0,05$ yang berarti dapat disimpulkan bahwa terdapat peningkatan secara signifikan pada kemampuan berpikir kritis kelompok eksperimen. Dan dikarenakan probabilitas (Sig.) $0,000<0,05$ maka H0 ditolak, artinya pembelajaran IPA berbasis empat pilar pendidikan efektif dalam meningkatkan kemampuan berpikir kritis siswa.

Tabel 8. Hasil Uji-T Dua Pihak

\begin{tabular}{|c|c|c|c|c|c|}
\hline & \multicolumn{5}{|c|}{ Paired Differences } \\
\hline & \multirow{3}{*}{$\begin{array}{l}\text { Std. } \\
\text { Dev }\end{array}$} & $95 \%$ Cinfidence & & \multirow{3}{*}{\multicolumn{2}{|c|}{ Df $\begin{array}{l}\text { Sig. (2- } \\
\text { tailed) }\end{array}$}} \\
\hline & & $\begin{array}{l}\text { Interval of } \\
\text { Difference }\end{array}$ & & & \\
\hline & & Lower Upper & & & \\
\hline $\begin{array}{l}\text { Pair } 1 \\
\text { pretes- } \\
\text { postes }\end{array}$ & 14.282 & $-42.524-32.226$ & -14.8 & 31 & .000 \\
\hline
\end{tabular}

Kurikulum 2013 yang diterapkan di Indonesia memberikan kesempatan guru untuk mengeksplorasi proses pembelajaran yang efektif dan inovatif. UNESCO sudah memperkirakan dalam perkembangan kurikulum pendidikan dengan munculnya empat pilar pendidikan untuk dimensi kualitas pendidikan. Hal ini ini didukung dengan Nan-Zhao (2005) kurikulum pendidikan harus dikemas dalam sebuah empat pilar pendidikan UNESCO memiliki impilikasi ke siswa yang bagus.

Berdasarkan penelitian pembelajaran berbasis empat pilar pendidikan ini juga dapat digunakan dalam inovasi pembelajaran untuk pembelajaran IPA. Sesuai dengan penelitian Kiswati (2012) juga menyatakan pengembangan pembelajaran yang berbasis empat pilar pendidikan UNESCO mendapat respon dan ketertarikan siswa dalam belajar.

Analisis data pada Tabel 6, menunjukan bahwa pembelajaran berbasis empat pilar pendidikan berpengaruh dalam kemampuan berpikir kritis siswa. Dengan hasil perhitungan ANACOVA mendapatkan signifikansi 0,026 yang artinya kurang dari signifikansi 0,05. Zhang (2003) menyatakan bahwa berpikir kritis siswa akan selalu ingin tahu, mencari jawaban yang tepat, dengan alasan yang tepat. Hal ini bagus dalam 
perkembangan pola pikir siswa yang dinamis.

Pada proses pembelajaran berbasis empat pilar pendidikan yang mempengaruhi keterampilan berpikir kritis sesuai dengan Tabel 9.

Tabel 9. Kesesuaian Empat Pilar Pendidikan dengan Keterampilan Berpikir Kritis

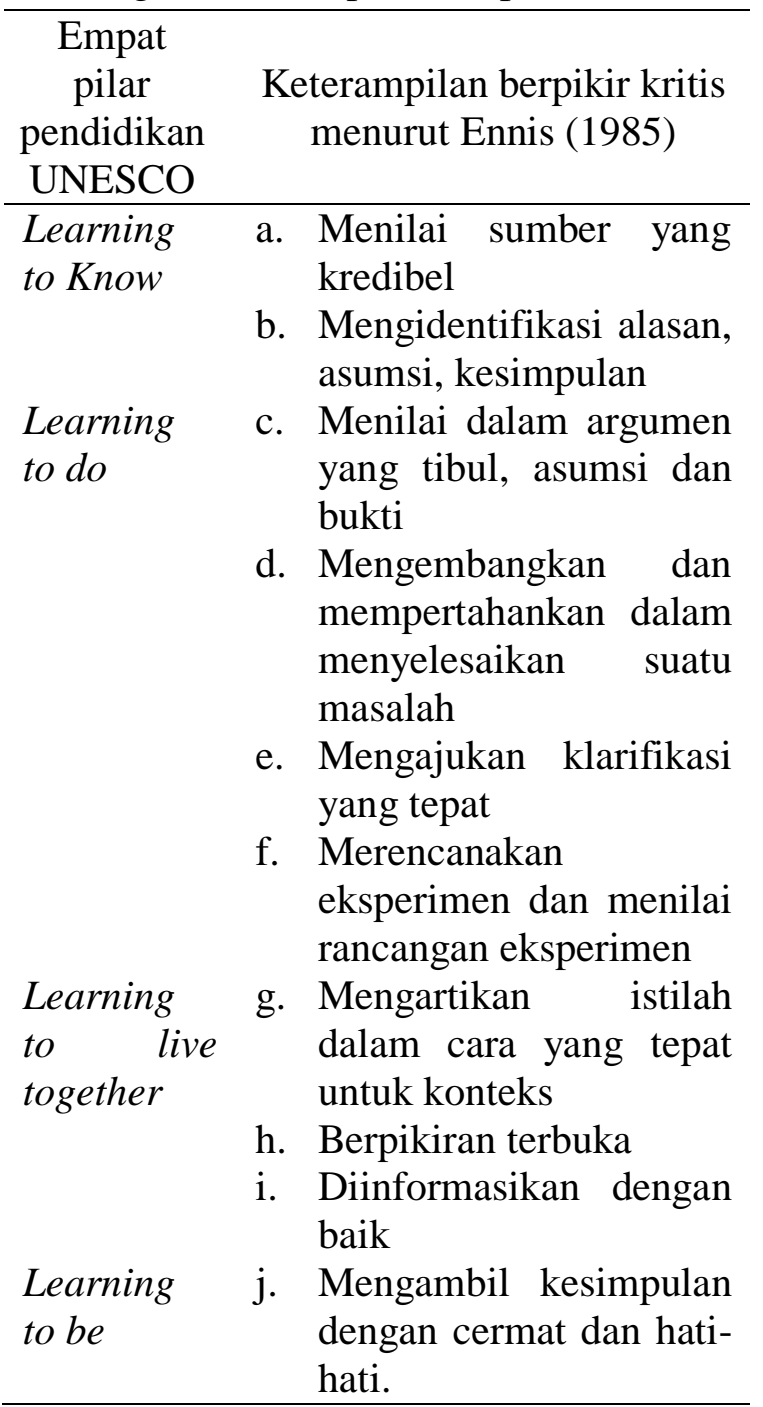

Learning to Know proses ini menumbuhkan keterampilan berpikir kritis dalam menilai sumber yang kredibel dengan rasa ingin tahu yang tinggi kemudian mengidentifikasi alasan, asumsi ataupun kesimpulan yang sudah ada untuk dijadikan landasan ataupun pedoman.
Learning to do proses ini mnejadikan siswa mengembangkan keterampilan dalam menilai argument yang muncul dari asumsi dan bukti yang sudah didapatkan, ditunjukan dengan perkembangan menyelesaikan masalah dengan mengajukan klarifikasi yang tepat. Melakukan eksperimen dan kelanjutan penyelesaian masalah melalui eksperimen tersebut.

Learning to live together proses ini mengembangkan keterampilan berpikir kritis siswa dalam mengkomunikasikan melalui istilah dan cara yang tepat sesuai dengan konteks. Berpikir terbuka dalam menerima saran dan kritik. Memberikan informasi sesuai dengan fakta.

Learning to be mengajarkan siswa dalam mengambil kesimpulan yang tepat, cermat dan hati-hati. Bahkan dalam penelitian Astuti, R. A., Aminah, N. S., \& Sukarmin, S. (2016) empat pilar pendidikan mampu meningkatkan sikap ilmiah siswa.

Berdasarkan pembahasan diatas membuktikan bahwa pembelajaran berbasis empat pilar pendidikan UNESCO mempengaruhi keterampilan berpikir kritis siswa. Didukung dengan data hasil efektivitas pembelajaran berbasis empat pilar pendidikan yang lebih efektif dari pembelajaran konvensional.

\section{SIMPULAN DAN SARAN}

Berdasarkan hasil dan pembahasan dapat disimpulkan bahwa terdapat pengaruh yang signifikan antara siswa yang menggunakan pembelajaran IPA berbasis empat pilar pendidikan dengan siswa yang menggunakan pembelajaran secara konvensional. Pembelajaran IPA berbasis empat pilar pendidikan efektif dalam meningkatkan kemampuan berpikir kritis siswa. 
Saran untuk penelitian selanjutnya yaitu mengembangkan bahan ajar dan media pembelajaran yang berbasis empat pilar pendidikan yang layak digunakan untuk pembelajaran IPA di SMP.

\section{UCAPAN TERIMA KASIH}

Kami menyampaikan terima kasih yang sebesar-besarnya kepada Direktorat Riset dan Pengabdian Kepada Masyakat (DRPM) Ditjen Penguatan Riset dan Pengembangan Kementerian Riset, Teknologi, dan Pendidikan Tinggi atas dukungan dana berupa hibah Penelitian.

\section{DAFTAR PUSTAKA}

Alfathy, R. M., Susanto, H., \& Marwoto, P. (2018). Penerapan Aktivitas Aesop's Berbantuan Guidance Worksheet untuk Meningkatkan Pemahaman Konsep Fisika dan Sikap Ilmiah. JIPVA (Jurnal Pendidikan IPA Veteran), 2(1), 48-57.

Asih, D. P. P., Supurwoko, S., \& Fauzi, A. (2015). Implementasi Modul Fisika SMA Berbasis Empat Pilar Pendidikan dengan Aplikasi Spreadsheet pada Materi Gerak Proyektil. In prosiding: Seminar Nasional Fisika dan Pendidikan Fisika, Vol. 6, No. 5. (pp.249-252). Surakarta.

Astuti, R. A., Aminah, N. S., \& Sukarmin, S. (2016). Pengembangan Modul IPA Terpadu Berbasis Empat Pilar Pendidikan Dengan Tema Pantai Untuk Meningkatkan Sikap Ilmiah Siswa Kelas VII SMP/MTS. Inkuiri, 5(2), 4051.

Butler, H. A. (2012). Halpern Critical Thinking Assessment predicts realworld outcomes of critical thinking. Applied Cognitive Psychology, 26(5), 721-729.

Ennis, R.H. (1985). A Logical Basis For Measuring Critical Thinking. dari http://www.ascd.org/ASCD/pdf/journal s/ed_lead/el_198510_ennis.pdf.

(diakses pada tanggal 22 mei 2017 jam 15.00 WIB)

Fauzi, A., Supurwoko, S., \& Wiyono, E. (2013). Potret Pembelajaran Fisika Berbasis Empat Pilar Pendidikan di SMA. In PROSIDING: Seminar Nasional Fisika dan Pendidikan Fisika (Vol. 4, No. 3).

Hakim, L., Suparmi, S., \& Masykuri, M. (2018). Pengembangan Perangkat Pembelajaran Fisika Berbasis Empat Pilar Pendidikan melalui OutdoorInquiry untuk Meningkatkan Kebiasaan Bekerja Ilmiah Pada Materi Momen Gaya, Fluida, Dan Keseimbangan Statis Di IKIP PGRI Pontianak. Inkuiri: Jurnal Pendidikan IPA, 6(3), 153-162.

Johnson, E.B. (2009). Contextual teachin \& learning (7th ed.). (Terjemahan Ibnu Setiawan). London: Sage Publications.

Kemendikbud (2012). Kompetensi dasar Kurikulum SMP 2013. Jakarta: Kementrian Pendidikan dan Kebudayaan.

Kiswati, K. (2012). Pengembangan Pembelajaran Matematika Dengan Pendekatan 4 (Empat) Pilar Pendidikan Unesco Pada Subbab Segiempat Di Kelas VII SMP Al Muhammad Cepu Blora. Dissertation, tidak dipublikasikan UIN Sunan Ampel Surabaya.

Nan-Zhao, Z. (2005). Four 'Pillars Of Learning' For The Reorientation And Reorganization Of Curriculum: Reflections And Discussions. International Bureau of EducationUNESCO.

Susetyo, Budi. (2008). Pengembangan Model Pembelajaran Fisika Berbasis Empat Pilar Pendidikan Melalui Outdoor - Inquiry Untuk Menumbuhkan Kebiasaan Bekerja Ilmiah. Thesis. tidak dipublikasikan Program Studi Pendidikan IPA. 
Program Pascasarjana Universitas Negeri Semarang

Yuliati, D. I., Yulianti, D., \& Khanafiyah, S. (2011). Pembelajaran fisika berbasis hands on activities untuk menumbuhkan kemampuan berpikir kritis dan meningkatkan hasil belajar siswa smp. Jurnal Pendidikan Fisika Indonesia, 7, 23-27.

Zhang, Li-Fang. (2003). Contributions of Thinking Styles To Critical Thinking Dispositions. Journal of Psychology, 137 (6), 517-543. 